\title{
The Writing Habits of Librarians
}

The writing habits of librarians were studied by citation counts in Library Literature. The data obtained show that persons holding a doctor's degree, whether in library science or in some other field, write an average of one publication per year. Persons holding a master's degree in library science write an average of 0.05 publications per year. Authors selected at random from Library Literature publish 0.20 items per year. The data point to a relationship between writing activity and the award of a doctor's degree.

Lists of prolific library science authors are given and compared to prolific authors in information science.

$\mathrm{T}_{\mathrm{r}}$ HE WRITING HABITS of most librarians are easily definable because Library Literature has provided an excellent author index to as complete a collection of library writings as is possible. One of the characteristics of librarians is that not only are they the collectors of what other people write, but also they have produced a large body of literature in which they have expressed their own views. Library Literature indexes material from over one hundred fifty periodicals, which gives the librarian wide latitude to publish. The aim of this study was to find a definable pattern in the writing habits of librarians whose work is indexed in $\mathrm{Li}$ brary Literature.

The writing habits of librarians have been alluded to in other writings, but no study completely devoted to them has been reported in the literature. Earlier work in this field includes articles by

Mr. Bloomfield is Supervisor, Culver City Library, Hughes Aircraft Company, Culver City, California. This paper is based upon a project conducted under the direction of Dr. Martha Boaz, Dean of the School of Library Science in the University of Southern California.
Danton, ${ }^{1}$ Harvey ${ }^{2}$ and Cuadra. ${ }^{3}$ These men have made studies in this field but from different points of view. Danton has made a thorough study of the characteristics of doctoral candidates and a portion of his article concerned the dissertations they wrote. Danton, however, slanted his study to an evaluation of the significance of the dissertation only rather than a quantitative study of the complete writings of the librarians. In the study by Harvey, which discusses the characteristics of the more successful librarians, there is no quantitative study of the librarians' writing. Harvey studied whether or not publications were a factor in the advancement of head college and public librarians. He said:

Were vertically mobile librarians more likely to have published books and magazine articles than their occupationally immobile colleagues? Yes, of course, and other studies of librarians and college professors have reached the same conclusion. Again, look-

\footnotetext{
1 J. Periam Danton, "Doctoral Study in Librarianship in the United States," CRL, XX (November 1959), 435-53.

'John F. Harvey, "Advancement in the Library Profession," Wilson Library Bulletin, XXXVI (October 1961), 144-47.

'Carlos A. Cuadra, "Identifying Key Contributions to Information Science," American Documentation, XV (Oetober 1964), 289-95.
} 
ing at the chief librarians at the highest levels, four-fifths (college) and one-half (public) of the librarians had published, while at the lowest level, only one-sixth (college) and one one-hundredth (public) had published. ${ }^{4}$

These data tend to show a relationship between advancement and publication.

Cuadra has attempted to rank the leading contributors to information science or the documentation field. He compiled a list of major contributors to the field by an analysis of the references in four bibliographies on information storage and retrieval. He counted the references for each author cited in the four bibliographies and then multiplied the four numbers. Thus Kent's total as given in Table 1 of 489,000 is the product of 39

'Harvey, op. cit., p. 146.

\section{TABLE 1}

The Highest Scornng Twenty-Frve Authors IN THE FIELD OF INFORMATION SCIENCE BY Publication Frequency

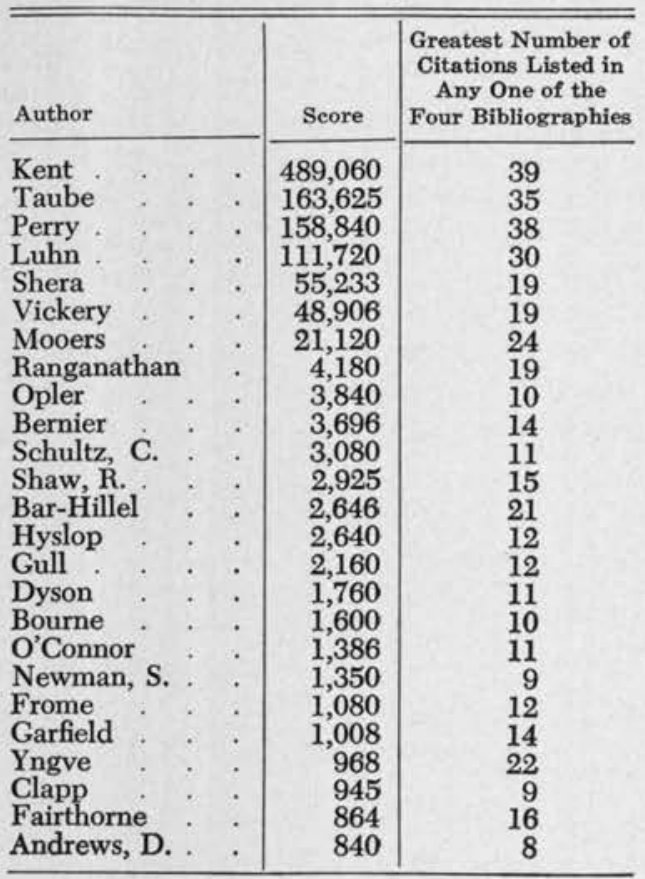

Note: Carlos A. Cuadra, "Identifying Key Contributions to Information Science," American Documentation, XV (October 1964), 293. citations times 33 citations times 19 citations times 20 citations. The other arbitrary numbers used in ranking the contributors were computed in the same way.

Table 1 shows the results of Cuadra's study. The greatest number of publications of any one author listed in any of the bibliographies is 39 . Table 1 has been included for comparative purposes with data that will be presented later in this paper.

No quantitative data are available from earlier studies, to determine writing activity of librarians. The aim of this study is to obtain such data and establish criteria for the writing activity of librarians.

\section{The Study}

This study is based entirely on material listed in Library Literature. The persons selected for this study came from three sources. First, the group of 171 holders of the doctor's degree in library science came from the articles by Danton $^{5}$ and Merritt. ${ }^{6}$ A second group of forty-two librarians who have doctor's degrees but whose major area of study for the degree was in some field other than library science was selected for the most part from library school catalogs. A third group of 172 librarians was selected who had written a master's thesis which was cited in Library Literature. And a fourth group of forty-seven authors was selected at random from the 1949-1951 issue of Library Literature. These last two groups were selected so that they would have had at least ten or more years to contribute to the literature. This was done so that time enough would be available to them for obtaining sufficient experience and maturity for productive writing. Also the average length of time from the award of the library science doctorate to the time of this study was ten years and therefore the same com-

\footnotetext{
${ }^{5}$ Danton, op. cit., p. 435.

- LeRoy C. Merritt, "Doctoral Study in Librarianship-A Supplement," CRL, XXIII (November 1962), 589-40.
} 
parative length of professional activity is afforded to the last two groups.

Several assumptions were made in conducting this study. First of all, the writing activity of librarians is limited to those publications cited in Library Literature. It is known that some of the authors have contributed to other fields besides library science, but any writing not indexed in Library Literature was considered to be outside the scope of this study. If a librarian writes on a political science subject, it will not be cited in Library Literature nor should it be considered within the literature of library science. A second assumption was that all citations in Library Literature have equal value. This is not true, but for many of the statistical tabulations this has been assumed. It goes without saying that a book is a far greater contribution to the field than is a review. One is an individual creative effort and the other is a response to that contribution. A third assumption was that $\mathrm{Li}$ brary Literature does indeed give a complete picture of the contributions of the people studied. And the final assumption made was that neither death nor marriage would have a significant effect on the statistical analysis. This study was taken through the September 1964 issue of Library Literature.

Once the four groups of librarians had been selected, Library Literature was searched to locate all the items indexed by each person. These citations were divided into several categories. Counts were made to determine how many articles, book reviews, and monographs were cited and whether or not a master's thesis or dissertation was cited. A count of one was given for a citation; a count of one-half was given for joint authorship, which will account for many of the fractional counts. Thus the final tally has some relationship to the publication production of a writing librarian.

Thus the statistical data in the following tables give the totals, the averages, and the medians of the citations found in Library Literature. The total and average figures are subdivided according to the kinds of publication, that is, master's

TABLE 2

Data for Library Science Doctorate Publications CTTED IN Library LTTERATURE

\begin{tabular}{|c|c|c|}
\hline & $\begin{array}{l}\text { Number of } \\
\text { Publications }\end{array}$ & $\begin{array}{l}\text { Average Number } \\
\text { of Publications } \\
\text { per Doctorate }\end{array}$ \\
\hline Total number of publications cited . . . & $3,199.5$ & $\begin{array}{c}18.6 \\
\text { (median } 8)\end{array}$ \\
\hline Number of master's theses cited & & \\
\hline Number of disserta & & \\
\hline Number of articles cited. & $2,102.5$ & 12.3 \\
\hline Number of book reviews cited & 693. & 4.05 \\
\hline Number of monographs cited & 228.5 & 1.34 \\
\hline $\begin{array}{l}\text { Total number of publications cited before the awarding of } \\
\text { the doctorate }\end{array}$ & 870 & 5.1 \\
\hline $\begin{array}{l}\text { Total number of publications cited after the awarding of } \\
\text { the doctorate }\end{array}$ & 070 & 1285 \\
\hline Publications written during the first year after the award of & $2,1 \mathrm{IC}$ & \\
\hline $\begin{array}{l}\text { the doctorate } \\
\text { Publications written during the second year after the award of }\end{array}$ & 178 & 1.04 \\
\hline the doctorate. & 156.5 & 0.91 \\
\hline $\begin{array}{l}\text { Publications written during the third and fourth year after the } \\
\text { award of the doctorate }\end{array}$ & 315.5 & 1.84 \\
\hline Publications written during the fifth to tenth year after the & & \\
\hline Publications written after the tenth year of holding the doctorate & 790.5 & $\begin{array}{l}4.34 \\
4.66\end{array}$ \\
\hline
\end{tabular}

Number of Doctorates Studied . 
thesis, doctoral dissertation, articles, book reviews, and monographs. The total number of publications for librarians with library school degrees is then broken down further by those publications which were written before and after the awarding of the degree. Since a date had to be established for the group of nonlibrary-science doctorates and random authors, the date of the first publication in Library Literature was assumed as a beginning date. These dates were then used to determine writing activity by years from the date of the first publication. These data are shown on the writing habits of librarians as a function of time from a given starting point.

\section{The Data}

\section{A. Library Science Doctorates.}

The data are presented according to the four groups of librarians. The first group to be studied is the library science doctorates. Table 2 shows the data accumulated for this group. A total of 171 librarians with doctorate degrees have written over three thousand items referenced in Library Literature. The average writing activity of this group was 18.6 items per doctorate, and the median was 8 . The lower figure for the median shows that there are a few prolific writers in this group. Included in Table 2 is the average number of articles, monographic works, and reviews they have written. Also the average number of master's theses and dissertations is listed. Note that the average number of dissertations is less than one, which means that a number of dissertations were omitted from Library Literature. Of the 171 people in this group, only 140 dissertations were indexed. Since the author, title, and date of the dissertation were given in the listings by Danton and Merritt, Library Literature was searched carefully to make sure that none of these dissertations were overlooked. When the dissertation was published as a journal article, it was not called a dissertation because the dissertation would be much longer than a journal article. Where the average number of dissertations indexed was 0.82 , the average number of master's theses indexed for the group was onequarter that number, or 0.2 . As would be expected, the article is the most used vehicle for the librarian to express his thoughts. Two-thirds of the publications for this group consisted of journal articles.

The library science doctorate wrote an average of 5.1 items before obtaining his doctor's degree. This is a point of significance. The doctoral candidate in library science is already a mature, experienced librarian before he obtains his advanced degree. As a result of the writing habits experienced before the award of the doctor's degree, these librarians continued writing at an extremely high rate after the award of the doctor's degree. In fact, the average doctorate writes about one article a year after he receives the doctor's degree. This is a high rate of writing in contrast to the average librarian who writes an estimated 0.05 items per year. Furthermore, it is the doctorates who raise the writing rate of the average librarian to the annual average of 0.05 publications. From Table 2, the average publication production per year for the first five years after the award of the doctorate is almost one per year.

In contrasting the writing of librarians with scientists, Price, in his book Little Science, Big Science, describes the scientific writing activity as:

Thus, for a field containing one thousand papers, there will be about three hundred authors. About 180 of them will not get beyond their first paper, but another will be above our cutoff of ten papers each, and ten will be highly prolific, major contributors. $^{7}$

The data collected for this paper show in a large measure that the trend in

\footnotetext{
$\tau$ Derek J. De Solla Price, Little Science, Big Science (New York: Columbia University Press, 1963 ), p. 49 .
} 
TABLE 3

Distribution of Publications Cited for LibraRy SCIENCE Doctorates BY Frequency of PUblication

Number of Doctorates 10

7

13

16

7

3

9
Number of Publications 1

8 (median) scientific publications described by Price is partially true for librarians as well. The library science doctorate produces on an average more than the Price cutoff level of ten publications. Price gives the definition of his cutoff point as:

If there are 100 authors, and the most prolific has a score of one hundred papers, half of all the papers will have been written by the ten highest scores, and the other half by those with fewer than ten papers each. In fact, in this ideal case, a full quarter of the papers have been written by the top two men and another quarter by those who publish only one or two items.

This immediately gives an objective method for separating the major from the minor contributors. One may set a limit and say that half the work is done by those with more than ten papers to their credit, or that the number of high producers seems to be the same order of magnitude as the square root of the total number of authors. ${ }^{8}$

The average number of publications of the library science doctorates is 18.6. Thus, if Price's criterion holds for library science authors, the people who strive to obtain the doctor's degree have by some process selected an average amongst them who will be in the most prolific writing segment of librarians.

Even though it is suggested that the holders of the doctorate are prolific, Table 3 shows the distribution of publications cited for library science doctorates by their frequencies of publication. Thus ten doctorates have written but one publication, twenty have written but two or three publications, sixteen have written four papers, and seven have written but five papers. The distribution curve would show the median at eight and the average at 18.6. The holder of the doctor's degree shows a far greater writing activity than Price suggests for scientists. Because the library science doctorate is a prolific writer, Table 4 was prepared to show the names of these writers, who are quite well known in the

sbid., p. 46. 
field. Dr. Jesse H. Shera led the field with 157 citations.

\section{B. Non-Library-Science Doctorates.}

The second group studied comprised forty-two librarians who received the doctorate in some field besides library science. Table 5 shows the data accumulated for this group. This group shows even greater writing activity than the library science doctorates. The average number of publications written by these librarians is twenty-seven, which is nine more than the average for the library science doctorates. The data for this group were gathered somewhat differently than data for the library science doctorates. Because the date for the award of the doctorate for this group was not readily available, statistics for their writing activity per year was based on the date of the first publication found for each author. This group, as well as the first group, averaged about one publication per year, which again is a high rate of activity.

Perhaps the same criteria of selection

\section{TABLE 4}

List of the Most Prolific AUthons with Library Science Doctoral Degrees

Number of Citations

Shera, J. H.

157

Carnovsky, L.

Shaw, R. R.

128.5

Tauber, M. F.

108.5

Ellsworth, R. E. . . . 80

Goldhor, H.

Merritt, L. C.

68

67.5

67

66.5

Martin, L. A.

65.5

60.5

57.5

56.5

50.5

49.5

49.5

46.5

41.5

41.5

41

41

40

39.5

38.5

\section{TABLE 5}

Data for Publications of Librarians Having Doctorates in Non-Library-Science Subjects Cited in Library Literature

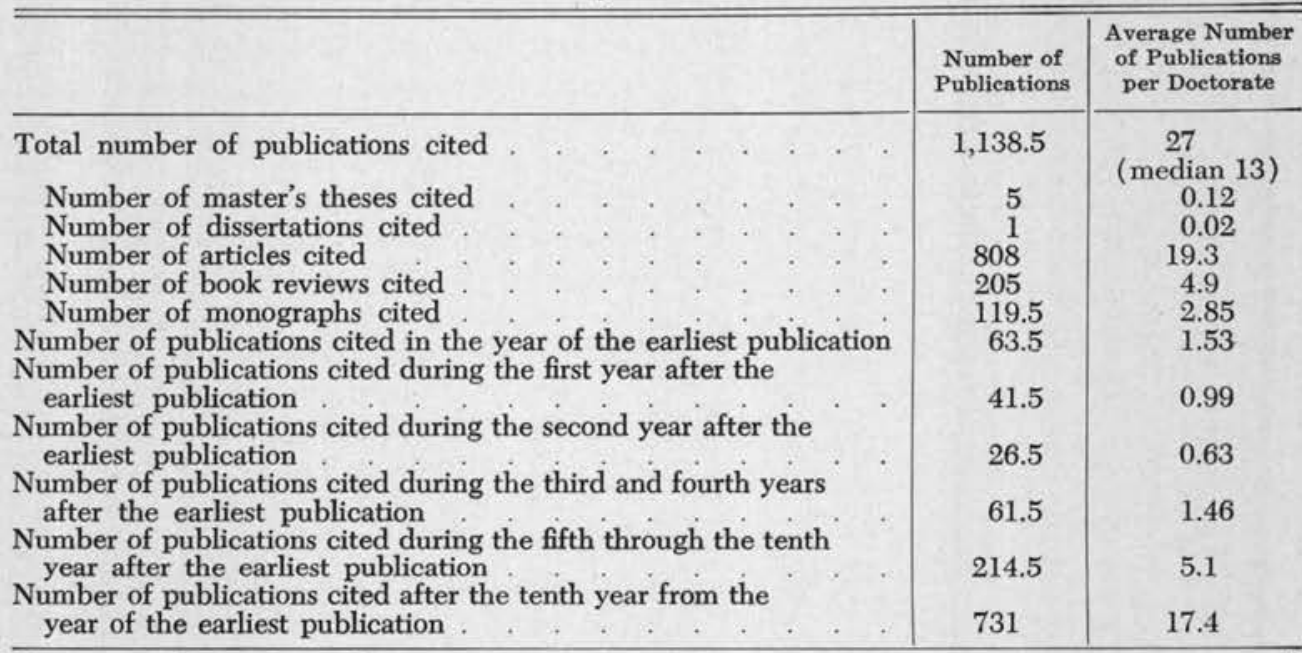

NUMBer of Doctorates Studied 
of these doctoral candidates took place as for the library science doctoral candidates. The subject area for the doctorate does not seem to have an effect on the writing activity of librarians. The writing activity of all librarians who hold doctorates is exceptionally high. Table 6 shows the distribution of publications per non-library-science doctorate. It shows a good deal of similarity to Table 3, and the two people with the greatest activity of both groups have almost the same number of publications. For library science doctorates, this number was 157 publications, for non-libraryscience doctorates, this number was 154 publications.

\section{TABLE 6}

\section{Distribution of Publications Cited for Librarians Having Doctorates IN NON-LIBRARY-SCIENCE SUBJECTS BY Frequency of Publication}

Number of Doctorates
Number of Publications 1 2 3 4 5 6 7
TABLE 7

List of the Most Prolific Non-LibrarySCIENCE DOCTORATES WITH OVER THIRTY-FIVE Crtations in Library Literature Number of Citations

Shores, L. 154

Powell, L. C.

Wilson, L. R.

144.5

120

Kuhlman, A. F.

Osborn, A. D.

71

60.5

Wight, E. A.

50.5

Dunkin, P. S.

Lancour, A. H.
Because the non-library-science doctorates were selected from library school catalogs, it would be expected that they are in the research atmosphere of a university and particularly in the environment of a library school. This environment may provide both the opportunity and desire to publish, which may well be the determining factor in this group's high rate of publication. Table 7 lists the non-library-science doctorates by name and the number of publications cited in Library Literature. In Table 7, Dr. Louis Shores leads the list with 154 publications. Since this list is not complete, there may well be other authors as prolific as Dr. Shores. Yet the productivity of publications by librarians does not come close to the high number cited by Price at 995 publications. ${ }^{9}$

It should be noted that for this group of non-library-science doctorates, the average number of citations for dissertations was 0.02 , which was just one dissertation indexed in Library Literature. This is to be expected from candidates whose major doctoral interest was not in library science. There were five master's theses indexed, which shows to some extent the switch in program for the doctorate but not the vocational goal set in the master's program.

\section{Librarians Whose Master's Theses Are Cited in Library Literature.}

The third group of librarians were those whose master's theses were cited

' Ibid., p. 49. 
TABLE 8

Data for Librarians Whose Master's Theses Were Cited in Library Literature

\begin{tabular}{|c|c|c|c|}
\hline & & $\begin{array}{l}\text { Number of } \\
\text { Publications }\end{array}$ & $\begin{array}{l}\text { Average Number } \\
\text { of Publications } \\
\text { per Librarian }\end{array}$ \\
\hline Total number of publications cited . . . . . . . . . . . . & & 420.5 & $\stackrel{2.44}{(\text { median } 1)}$ \\
\hline Number of master's theses cited. & . & 172 & \\
\hline Number of dissertations cited. & : & & 0.02 \\
\hline Number of articles cited. & & 196 & 1.15 \\
\hline Number of book reviews cited & & 32.5 & 0.19 \\
\hline Number of monographs cited & & 17 & 0.10 \\
\hline Total number of publications cited before the award of the & & & \\
\hline $\begin{array}{l}\text { master's degree } \\
\text { Total number of publications cited after the award of the }\end{array}$ & & 34 & 0.2 \\
\hline master's degree & & 214.5 & 1.25 \\
\hline $\begin{array}{l}\text { Publications cited during the first year after the award of the } \\
\text { master's degree }\end{array}$ & & 13 & 0.08 \\
\hline $\begin{array}{l}\text { Publications cited during the second year after the award of } \\
\text { the master's degree }\end{array}$ & & 10 & \\
\hline Publications cited during the third and fourth year after the & & $y$ & \\
\hline Publications cited during the fifth through the tenth $y$ & & & 0.13 \\
\hline & & 90.5 & 0.53 \\
\hline $\begin{array}{l}\text { Publications cited after the tenth year of the award of the } \\
\text { master's degree }\end{array}$ & & 80.5 & 0.47 \\
\hline
\end{tabular}

Number of Libraruans Studied

in Library Literature. The fact that these people had their theses indexed might have spurred them to further publishing. However, their annual publication production only equals the estimated average librarian's rate of 0.05 publications per year.

This group of 172 librarians did very poorly in their publications production in contrast to the librarians with doctorates. Their total average publication rate was 2.44 , and the median was just one. That the median was one shows that at least half of the group did not write any kind of a publication after they won their master's degrees. Of the group selected, three library science doctorates produced 30 per cent of the publications other than master's theses. Table 8 shows the data accumulated for the 172 librarians. The publication rate before the awarding of the master's degree was an average of one-fifth of a publication per librarian. The average annual publication rate in this group after the award of the master's degree was one publication per fifteen librarians. The average pub- lication rate per year per doctorate was about ten times this figure or about one publication per year. It would be expected that as the holders of master's degrees gained experience, their writing activity would increase. In the period from five to ten years after the awarding of the master's degree, this group of librarians was producing only slightly more publications than it had during the first year after the degree was granted. There is an increase in production of publications, but it is small. The total publication activity of this group was almost equally divided between the master's theses which were written in library school and the articles, book reviews, and monographs which were published after their graduation. Apparently the writing of a master's thesis which is cited in Library Literature does not spur a librarian to publish after his graduation from library school.

Table 9 shows the number of librarians in this group and the number of publications they have written. The distribution curve for the number of pub- 
TABLE 9

Distribution of Publications CrTed For Libraruans Whose Master's Theses Were CrTED in Library LtTERAture

Number of Librarians Number of Publications

\begin{tabular}{|c|c|c|c|c|c|}
\hline 124 & . & . & . & . & 1 (median) \\
\hline 19 & . & . & . & . & 2 (average) \\
\hline 8 & . & . & . & . & 3 \\
\hline 6 & . & . & . & . & 4 \\
\hline 4 & . & . & . & . & 5 \\
\hline 1 & . & . & . & . & 6 \\
\hline 1 & . & . & . & . & 7 \\
\hline 0 & . & . & . & . & 8 \\
\hline 2 & . & . & . & . & 9 \\
\hline 0 & . & . & . & . & 10 \\
\hline 2 & . & . & . & . & 11 \\
\hline 1 & . & c. & . & . & 12 \\
\hline 1 & . & . & . & . & 16 \\
\hline 1 & . & . & . & . & 19 \\
\hline 1 & . & . & . & . & 31 \\
\hline 1 & . & . & . & . & 67 \\
\hline
\end{tabular}

lications this group has written shows that 124 librarians have written only the master's thesis, and this after some twelve to fourteen years of experience. The highest productivity of this group was a librarian who had written sixtyseven publications. This individual is F. L. Schick, who can be found in Table 4 with the listing of the library science doctorates. By chance, his master's thesis fell into the sample taken for this group. Two other doctorates fell into this category, but their publication production did not equal Dr. Schick's. Because this group did not show outstanding publication activity, a list of names comprising it was not considered necessary.

\section{Authors Chosen at Random From Library Literature.}

For contrast with the librarians holding doctor's and master's degrees, another group of authors was selected from the 1949-1951 issue of Library Literature. This group should have resembled the group cited for master's theses in that they were chosen by almost the same method. The librarians with master's degrees were chosen because their theses were cited in Library Literature. The members of this group were chosen because they were cited in Library Literature for some other kind of publication indexed during the period of time from 1949 to 1951 . From Table 10, it can be seen that ten of the forty-seven librarians of this group had master's theses cited. Nine of these ten master's

Data for Authors Chosen at Random in Libraky Literature

\begin{tabular}{|c|c|c|c|}
\hline . & & $\begin{array}{l}\text { Number of } \\
\text { Publications }\end{array}$ & $\begin{array}{l}\text { Average Number } \\
\text { of Publications } \\
\text { per Librarian }\end{array}$ \\
\hline Total number of publications cited . . . . . . . & & 268.5 & \\
\hline $\begin{array}{l}\text { Number of master's theses cited } \\
\text { Number of dissertations cited } \\
\text { Number of articles cited } \\
\text { Number of book reviews cited } \\
\text { Number of monographs cited }\end{array}$ & & $\begin{array}{r}10 \\
1 \\
229 \\
22 \\
6.5\end{array}$ & $\begin{array}{l}0.21 \\
0.02 \\
4.86 \\
0.42 \\
0.14\end{array}$ \\
\hline $\begin{array}{l}\text { Number of publications cited in the year of the earliest } \\
\text { publication }\end{array}$ & & 57.5 & 1.2 \\
\hline $\begin{array}{l}\text { Number of publications cited in the first year after the } \\
\text { earliest publication }\end{array}$ & & 24.5 & 0.52 \\
\hline $\begin{array}{l}\text { Number of publications cited in the second year after the } \\
\text { earliest publication. } \\
\text { Number of publications cited in the third and fourth year }\end{array}$ & & 13.5 & 0.29 \\
\hline $\begin{array}{l}\text { Number of publications cited in the third and fourth year } \\
\text { after the earliest publication }\end{array}$ & & 22 & 0.46 \\
\hline $\begin{array}{l}\text { Number of publications cited in the fifth through the tenth } \\
\text { years after the earliest publication }\end{array}$ & & 57.5 & 1.2 \\
\hline $\begin{array}{l}\text { Jumber of publications cited after the tenth year from the } \\
\text { year of the earliest publication }\end{array}$ & & 93.5 & 2.0 \\
\hline
\end{tabular}

NUMBER OF Librarians StUdied 
theses were the only publications which caused their authors to fall in this group. Also from Table 10, it can be seen that only one dissertation was cited.

This group started with a base of forty-seven publications before a search was made for additional publications. The fact that the group had been publishing some articles and monographs gave them the incentive to continue their writing activity. As a group, the average number of publications produced was 5.7. This is almost two and a half times the activity of the group of librarians whose master's theses were cited. Despite this high average, the median number of publications per librarian for this group was one. That is to say, half of this group wrote one publication and then stopped.

In the first ten years after the earliest citation in Library Literature, this group was more likely to publish within a year of the first publication, than in any of the next nine years. Table 11 shows the number of librarians who had been cited for a given number of publications. Again there is no listing of names because it was felt that a publication activity of twenty-five, the highest number

\section{TABLE 11}

Distribution of Publications for Librarians Who Were CrTed in Library Literature by Frequency of PUblication

Number of Librarians

22

7

1

0

2

1

2

2

1

0

3

1

4

1
Number of Publications

1 (median)

2

3

4

5

6 (average)

7

8

9

10

16

19

21

25 for this group, fell far short of that for the librarians with doctorates, which had a top of 157 publications. All the authors listed by name in Tables 4 and 7 had more than thirty-five publications to their credit.

\section{Discussion}

The data as given above in Tables 2, 5,8 and 10 have been summarized in Table 12. There are a few trends that can thus be seen. First, throughout each of the groups selected, article production is by far the most frequent method of expression. The next most frequent method of publication is the book review. And the least frequent method of publication is the monograph. For this comparison, the thesis is not considered a method of publication because it is school-connected. Few people decide to write a thesis except under the urging of a classroom instructor. Despite the effort that is necessary to write a monograph, there is still quite a high incidence of monographic work done. The average of over one monograph per doctorate indicates that the awarding of a doctor's degree and the writing of a fairly substantial dissertation may give a person enough experience and impetus to continue after graduation to write books and reports.

It should be noted that there is very little comparison between the list prepared by Cuadra as given in Table 1 and the lists of doctorates as given in Tables 4 and 7. Only two names appear in common among these three lists. The names of Dr. Shera and Dr. Shaw appear in Cuadra's list and in the list of the most prolific library science doctorates. If information science is the frontier of research in library science disciplines, then it is clear that most of the research is being conducted outside the areas of study by the library science doctorates. Librarians, whether holding advanced degrees or not, have left research in documentation to be done by men who have 
TABLE 12

Summary of Data of Writing Activtry by Librarians Given in Average Publications per Author

\begin{tabular}{|c|c|c|c|c|}
\hline & $\begin{array}{c}\text { Library } \\
\text { Seience } \\
\text { Doctorates }\end{array}$ & $\begin{array}{l}\text { Non-Library- } \\
\text { Seience } \\
\text { Doctorates }\end{array}$ & $\begin{array}{l}\text { Librarians with } \\
\text { Master's Theses } \\
\text { Cited }\end{array}$ & $\begin{array}{l}\text { Librarians } \\
\text { Chosen from } \\
\text { Citation in } \\
\text { Library } \\
\text { Literature }\end{array}$ \\
\hline $\begin{array}{l}\text { Number of master's theses } \\
\text { cited } \\
\text { Number of dissertations cited } \\
\text { Number of articles cited } \\
\text { Number of book reviews cited } \\
\text { Number of monographs cited } \\
\text { Total number of publications } \\
\text { cited } \\
\text { Publications cited in years after either } \\
\text { award of degree or first publica- } \\
\text { tion: } \\
\text { First } \\
\text { Second } \\
\text { Third and fourth } \\
\text { Fifth to tenth } \\
\text { After tenth }\end{array}$ & $\begin{array}{c}0.20 \\
0.82 \\
12.30 \\
4.05 \\
1.34 \\
18.60 \\
\text { (median } 8 \text { ) }\end{array}$ & $\begin{array}{c}0.12 \\
0.02 \\
19.30 \\
4.90 \\
2.85 \\
27.0 \\
\text { (median } 13 \text { ) }\end{array}$ & $\begin{array}{c}1.00 \\
0.02 \\
1.15 \\
0.19 \\
0.10 \\
2.44 \\
\text { (median 1) }\end{array}$ & $\begin{array}{c}0.21 \\
0.02 \\
4.86 \\
0.42 \\
0.14 \\
5.70 \\
\text { (median 1) }\end{array}$ \\
\hline
\end{tabular}

obtained their education and experience outside the library environment.

Because of the scope of this study, the significance or area of publications was not considered. It might be of value for a study to relate the reasons for the lack of correlation between the prolific authors holding library science doctorates and the prolific authors of documentation literature.

\section{Conclusions}

Certain patterns of writing habits among librarians can be discerned from the data accumulated for this study. The librarians who obtain doctorates write substantially more than librarians without the degree. To obtain a doctorate means that a person must work diligently, usually beyond the demands made on the average librarian. The selection process perhaps filters the applicants for the doctorate so that only the hard workers and diligent writers are awarded the degree. The doctorate seems to be a difference in writing productivity whether the degree was in library science or in some other field. The citation of the master's thesis in Library Literature does not seem to have any effect on the publication activity after the award of the master's degree. Authors chosen at random from citations in Library Literature produced significantly more publications than the average librarian, but did not compare to the productivity of the doctorate.

\section{MOVING . .}

\section{(Continued from page 108)}

aries of all library personnel taking part must be included in the over-all cost, and the library neglecting to do this deceives only itself. Even so, the cost of hiring a moving company to do the job can be almost astronomical, exceeding by three to five times the cost of an internal operation; because, though recognizing that the library must account for its own staff time, regardless of who actually moves the books, the burden of planning and supervision must by necessity be borne by the library staff. 